\title{
Precipitation as the main driver of Neoglacial fluctuations of Gualas glacier, Northern Patagonian Icefield
}

\author{
S. Bertrand ${ }^{1,2,3}$, K. A. Hughen ${ }^{1}$, F. Lamy ${ }^{2}$, J.-B. W. Stuut ${ }^{4,5}$, F. Torrejón ${ }^{6,7}$, and C. B. Lange ${ }^{8}$ \\ ${ }^{1}$ Marine Chemistry and Geochemistry, Woods Hole Oceanographic Institution, Woods Hole, MA, USA \\ ${ }^{2}$ Alfred Wegener Institute, Bremerhaven, Germany \\ ${ }^{3}$ Renard Centre of Marine Geology, University of Ghent, Belgium \\ ${ }^{4}$ MARUM, Center for Marine Environmental Sciences, University of Bremen, Germany \\ ${ }^{5}$ NIOZ Royal Netherlands Institute for Sea Research, Texel, The Netherlands \\ ${ }^{6}$ EULA Center, University of Concepción, Chile \\ ${ }^{7}$ Patagonian Ecosystems Research Center (CIEP), Coyhaique, Chile \\ ${ }^{8}$ Department of Oceanography and COPAS Center, University of Concepción, Chile
}

Correspondence to: S. Bertrand (sbertrand@whoi.edu)

Received: 2 September 2011 - Published in Clim. Past Discuss.: 19 September 2011

Revised: 21 December 2011 - Accepted: 29 December 2011 - Published: 15 March 2012

\begin{abstract}
Glaciers are frequently used as indicators of climate change. However, the link between past glacier fluctuations and climate variability is still highly debated. Here, we investigate the mid- to late-Holocene fluctuations of Gualas Glacier, one of the northernmost outlet glaciers of the Northern Patagonian Icefield, using a multi-proxy sedimentological and geochemical analysis of a $15 \mathrm{~m}$ long fjord sediment core from Golfo Elefantes, Chile, and historical documents from early Spanish explorers. Our results show that the core can be sub-divided into three main lithological units that were deposited under very different hydrodynamic conditions. Between 5400 and $4180 \mathrm{cal} \mathrm{yr} \mathrm{BP}$ and after 750 cal yr BP, sedimentation in Golfo Elefantes was characterized by the rapid deposition of fine silt, most likely transported by fluvio-glacial processes. By contrast, the sediment deposited between 4130 and $850 \mathrm{cal} \mathrm{yr} \mathrm{BP}$ is composed of poorly sorted sand that is free of shells. This interval is particularly marked by high magnetic susceptibility values and $\mathrm{Zr}$ concentrations, and likely reflects a major advance of Gualas glacier towards Golfo Elefantes during the Neoglaciation. Several thin silt layers observed in the upper part of the core are interpreted as secondary fluctuations of Gualas glacier during the Little Ice Age, in agreement with historical and dendrochronological data. Our interpretation of the Golfo Elefantes glaciomarine sediment record in terms of fluctuations of Gualas glacier is in excellent agreement with the glacier chronology proposed for the Southern Patagonian Icefield, which is based on terrestrial (moraine)
\end{abstract}

deposits. By comparing our results with independent proxy records of precipitation and sea surface temperature, we suggest that the fluctuations of Gualas glacier during the last $5400 \mathrm{yr}$ were mainly driven by changes in precipitation in the North Patagonian Andes.

\section{Introduction}

Understanding the response of terrestrial environments to past changes in climate is a fundamental aspect of paleoclimate research. In this respect, very little is known about the Holocene fluctuations of the outlet glaciers of the Northern Patagonian Ice Field (NPI) and their climatic causes. In addition, although glacier fluctuations are frequently used as indicators of climate changes, the individual roles of the different climatic parameters that affect their mass balance (i.e. precipitation, temperature) remain highly debated.

In Patagonia there is considerable evidence that glaciers and icefields have expanded and contracted during the Holocene. However, most of the evidence comes from outlet glaciers of the Southern Patagonian Icefield (SPI; Glasser et al., 2004). Only a few of the NPI outlet glaciers have been studied in detail. Most authors have focused on quantifying changes in glacier length and area during recent decades (Aniya, 1992; Rivera et al., 2007; López et al., 2010), or on dendrochronological records of moraines and trimlines formed during the last two centuries (Winchester 
and Harrison, 1996; Harrison and Winchester, 1998; Harrison et al., 2007, 2008). Reconstructions of earlier NPI glacier fluctuations are generally limited to a few radiocarbon ages obtained on organic deposits within or overlying frontal moraines (Heusser, 1960; Mardones et al., 2011). These radiocarbon ages are generally assumed to provide close minimum ages, but their reliability has been questioned (Porter, 2000). In addition, attempts to reconstruct glacier fluctuations using cosmogenic radionuclides and optically stimulated luminescence techniques were only partly successful (Harrison et al., 2008).

In the literature, glaciers are generally considered as faithful indicators of climate change. However, the sensitivity of a glacier to climate change depends on its geometry, on the specific regional climatic setting, and on the physics governing ice behavior (Oerlemans, 2005; Yde and Paasche, 2010). Surging and calving glaciers, for example, may vary independently of climate, especially on short time-scales (Mann, 1986; Warren, 1993; Warren and Aniya, 1999; Pfeffer, 2003; Yde and Paasche, 2010; Post et al., 2011). In addition, glacier mass balance depends on the combination of multiple climatic parameters such as air temperature, solar radiation, and precipitation (Oerlemans, 2005). It is therefore crucial to understand the influence of each of these parameters on specific glaciers before interpreting past glacier changes in terms of paleoclimate variability.

By comparing meteorological and historical data, Warren (1993) proposed that the variations of San Rafael glacier (southwestern NPI) during the last century (since 1920) were mainly driven by changes in winter precipitation. A similar conclusion was reached for San Quintin, Reicher and Gualas glaciers which are all located on the western side of the NPI (Winchester and Harrison, 1996; Harrison and Winchester, 1998). Whether this relation is valid prior to the last century, i.e. under different climate boundary conditions, has yet to be assessed. The only attempt to understand Patagonian glacier variability in the context of paleoclimate changes was made by Glasser et al. (2004). These authors argue that Holocene variations of Patagonian glaciers can be explained by changes in precipitation and atmospheric temperature, but they did not systematically compare glacier variability to regional paleoclimate records.

In this paper, we tackle these issues by (1) investigating the mid- to late-Holocene fluctuations of Gualas glacier, one of the northernmost outlet glaciers of the NPI, and (2) comparing the results to independent precipitation and temperature proxy records from the same region, to assess the influence of climatic parameters on western NPI outlet glaciers variability. For the first time, we reconstruct the fluctuations of an outlet glacier of the NPI by combining a glaciomarine sediment record with historical data from the Spanish explorers.

\section{Regional setting}

NPI has a total area of $4197 \mathrm{~km}^{2}$ and caps the Andean Cordillera between altitudes of 700 and $2500 \mathrm{~m}$ a.s.l. (Fig. 1a; Rivera et al., 2007). It is composed of 70 glaciers larger than $0.5 \mathrm{~km}^{2}$, many of which, such as Gualas, are outlet glaciers. NPI is nourished by moisture transported from the Pacific Ocean by the westerly winds, which results in high precipitation throughout the year, and a strong west-east precipitation gradient due to the rain shadow effect of the Andes (Warren, 1993). Precipitation is highest in winter but displays a relatively weak seasonal pattern. The mass balance of the NPI has been increasingly negative during the last decades (Rignot et al., 2003), contributing $0.013 \pm 0.006 \mathrm{~mm} \mathrm{yr}^{-1}$ (Rivera et al., 2007) or $0.0018 \pm 0.0004 \mathrm{~mm} \mathrm{yr}^{-1}$ (Glasser et al., 2011) to global sea-level rise.

Gualas glacier is one of the northernmost western NPI glaciers. It has a total area of $119.2 \mathrm{~km}^{2}$ and a length of $32 \mathrm{~km}$ (Rivera et al., 2007; López et al., 2010). It originates from Monte San Valentin at $3910 \mathrm{~m}$ a.s.l. and it dips towards the west with an average gradient of $7.9 \%$ (Aniya, 1988). In the present-day setting, an 8-km long proglacial river (Gualas river) flows from Gualas proglacial lake to Golfo Elefantes (Fig. 1b). According to Fernandez et al. (2012), Golfo Elefantes remained free of ice during the last $\sim 11.3 \mathrm{kyr}$, and the large terminal moraines that occur along the edges of Golfo Elefantes (MSI and MSII on Fig. 1b) were formed at the end of the local Last Glacial Maximum ( $>11.3 \mathrm{kyr}$ ). Gualas river is also fed by the meltwater of Reicher glacier, through its own proglacial lake (Fig. 1c).

Although only a few of the NPI outlet glaciers have been studied in detail, the available records show a general retreat of the western NPI glaciers, including Gualas, during the last $150 \mathrm{yr}$. Using aerial photographs, Aniya (1988) measured a retreat of $350-600 \mathrm{~m}$ of Gualas glacier between 1944 and 1986, while López et al. (2010) note a retreat of $1.5 \mathrm{~km}$ between 1979 and 2005. According to Harrison and Winchester (1998), Gualas glacier retreated from its "Little Ice Age" position during the 1870s, and showed additional marked retreats during the 1920s-1930s and 1960s1970s. This recent behavior is consistent with the retreat of Reicher, San Rafael, and San Quintin glaciers (Harrison and Winchester, 1998), which tends to indicate that these glaciers are mainly driven by climate, and are not surgingtype glaciers (e.g. Post et al., 2011). As indicated by Warren and Aniya (1999), Gualas glacier may currently suffer from accelerated retreat due to calving processes in its newly formed proglacial lake. 

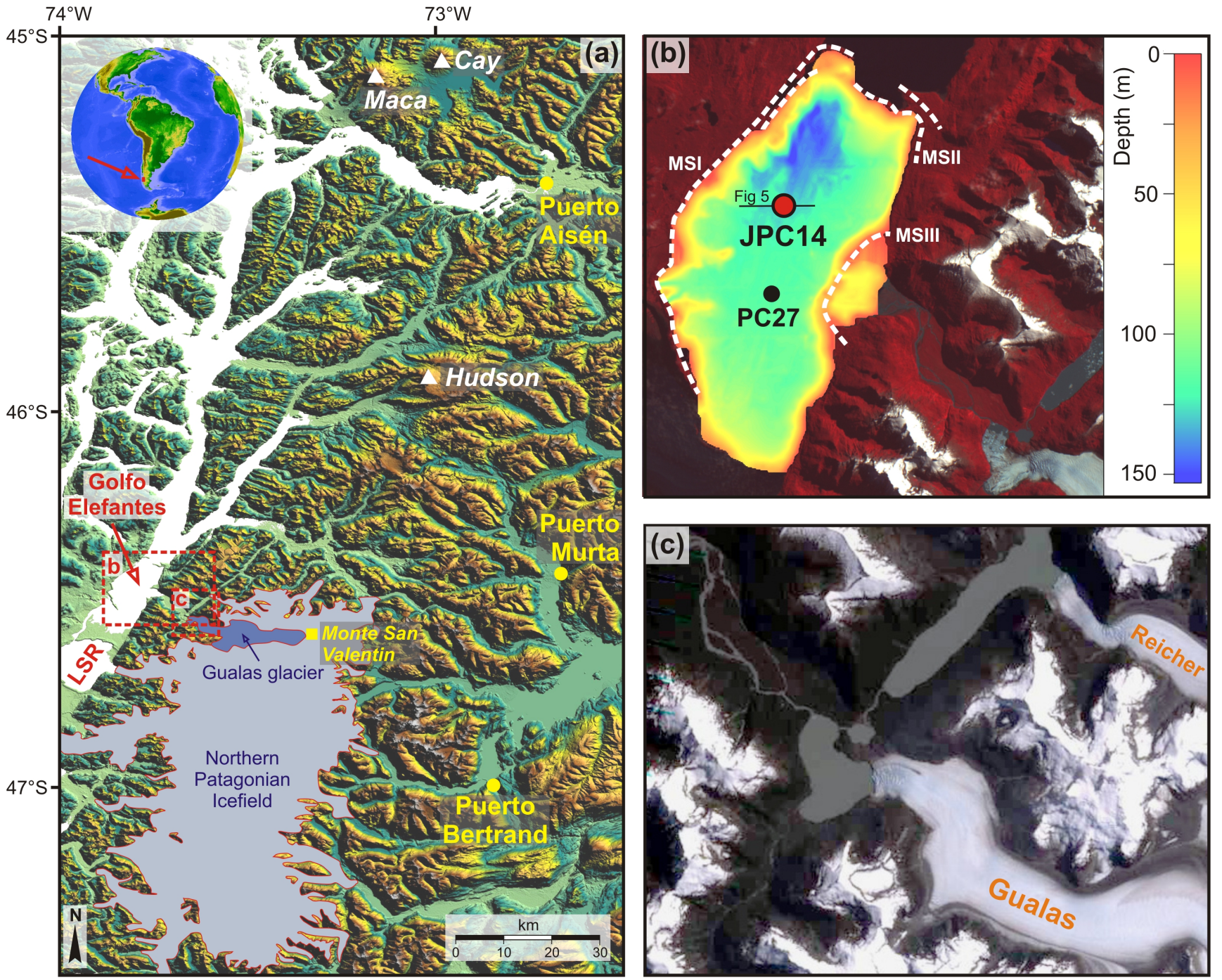

Fig. 1. Location of Gualas glacier and Golfo Elefantes in Northern Chilean Patagonia. (a) Regional map with indication of the main towns (•) and regional volcanoes $(\Delta)$. LSR: Laguna San Rafael. (b) Location of sediment cores JPC14 and PC27 in Golfo Elefantes. The background is a false color 2001 Landsat image (bands 2,3,4) where dense vegetation is represented by bright red colors. Bathymetrical data are from SHOA (Hydrographic and Oceanographic Service of the Chilean Navy; bathymetric map Golfo Elefantes and Laguna San Rafael) and from Fernandez et al. (2012). The location of seismic line 5 (see Fig. 5) is also indicated. MSI, II and III refer to Gualas Moraine systems I, II and III, according to Heusser (1960) and Fernandez et al. (2012). (c) Landsat image (16 February 2010) of the ice fronts of Gualas and Reicher glaciers.

\section{Material and methods}

\subsection{Coring and sediment sampling}

Sediment core JPC14 $\left(46.449^{\circ} \mathrm{S}-73.798^{\circ} \mathrm{W}\right)$ was collected in 2005 in the central basin of Golfo Elefantes at a depth of $129 \mathrm{~m}$ during cruise NBP05-05 on board the RVIB Nathaniel B. Palmer (Fig. 1). The $15 \mathrm{~m}$ long jumbo piston core was split and described on board, and subsequently sent to the Antarctic Marine Geology Research Facility of Florida State University for cold storage. In 2008, a complete core half was shipped to the Woods Hole Oceanographic Institution (MA, USA) for XRF core scanning, magnetic susceptibility (MS) logging, and sampling. Samples $(3 \mathrm{cc})$ were taken every $10 \mathrm{~cm}$ with a plastic syringe and immediately freeze-dried. Wet and dry sample weights were recorded for water content calculation. Additional small $(\sim 0.1 \mathrm{cc})$ samples were taken every 2 to $4 \mathrm{~cm}$ for grain size analysis, and kept wet in microcentrifuge tubes. Shell and leaf/wood remains were also collected from both core halves for radiocarbon dating. These samples were cleaned and sent to NOSAMS for analysis. In addition, we analyzed sediment 
core PC27 $\left(46.484^{\circ} \mathrm{S}-73.804^{\circ} \mathrm{W}\right.$; depth: $112 \mathrm{~m}$; length: $142.5 \mathrm{~cm}$; Fig. 1b), which was collected during the CIMAR (Cruceros de Investigación Marina) 7 Fiordos expedition in November 2001 (R/V AGOR Vidal Gormáz, Chile) and sampled at WHOI in $1 \mathrm{~cm}$ thick slices.

\subsection{Radiocarbon dating}

Ten AMS radiocarbon ages were obtained on organic $(n=4)$ and inorganic $(n=6)$ macro-remains picked in sediment core JPC14, and two in core PC27 (Table 1). No material suitable for dating was found between 1200 and $750 \mathrm{~cm}$ in core JPC14. Radiocarbon ages were calibrated with OxCal 4.1.5, using the calibration curve SHCal04 (McCormac et al., 2004). The local reservoir age $(480 \mathrm{yr})$ was calculated as the difference between radiocarbon results obtained on terrestrial organic and marine inorganic carbon samples at $217-200 \mathrm{~cm}$. The value of $480 \mathrm{yr}$ is relatively similar to the reservoir age of $530 \mathrm{yr}$ that is commonly used for the eastern South Pacific (e.g. Mohtadi et al., 2007).

\subsection{Inorganic geochemistry}

The inorganic geochemistry of sediment cores JPC14 and PC27 was measured with an ITRAX XRF core scanner (CoX Analytical Instruments) at a resolution of 2 and $1 \mathrm{~mm}$, respectively. The scanner was operated with $20 \mathrm{~s}$ scan times using a Mo X-Ray tube set to $30 \mathrm{kV}$ and $45 \mathrm{~mA}$. Here, we use the $\mathrm{Zr}$ counts as a proxy for sediment grain size in proximal environments following Bertrand et al. (2012).

A subset of 44 samples from core JPC14 was analyzed for inorganic geochemistry by ICP-AES. Samples were prepared using the Li-metaborate ( $\mathrm{LiBr}$ ) fusion technique of Murray et al. (2000), which is preferred over HF digestion because it is the only technique that allows the complete dissolution of sediment samples containing refractory minerals such as zircon (Huang et al., 2007). Sample preparation consisted of mixing $200 \pm 1.0 \mathrm{mg}$ of ultrapure Li-metaborate (SCP Science) in $3 \mathrm{ml} \mathrm{Pt:Au} \mathrm{(95:5)} \mathrm{crucibles,} \mathrm{with} 50 \pm 0.5 \mathrm{mg}$ of sediment. Ten $\mu \mathrm{l}$ of $25 \% \mathrm{LiBr}$ were then added to the mixture and the crucibles were placed in a muffle furnace for $12 \mathrm{~min}$ at $1050^{\circ} \mathrm{C}$. The newly formed glass bead was then allowed to cool down for 2-3 min, detached from the crucible, and poured into a Teflon beaker containing a swirling $25 \mathrm{ml}$ solution of $5 \% \mathrm{HNO}_{3}$. Complete dissolution occurred within $\sim 30 \mathrm{~min}$. The solution was then filtered through a $0.45 \mu \mathrm{m}$ PVDF Millipore filter and diluted in $5 \% \mathrm{HNO}_{3}$ to obtain a $4000 \times$ final dilution of the sample. The exact dilution factor was calculated from the precise weight of sediment used for fusion.

Thirteen elements were measured on a JY Ultima C ICPAES. Analytical details are given in Bertrand et al. (2012). Here, we report the concentrations of $\mathrm{Si}, \mathrm{Al}$, and $\mathrm{Zr}$, and the ratios between these elements. Analytical precision $(1 \sigma)$, which was calculated from the analysis of ten individually-prepared sub-samples of reference sediment PACS-2, is $0.66 \%$ for $\mathrm{Al}, 0.68 \%$ for $\mathrm{Si}$, and $4.18 \%$ for $\mathrm{Zr}$. Precision for the elemental ratios is $0.12 \%(\mathrm{Si} / \mathrm{Al})$ and $3.87 \%$ ( $\mathrm{Zr} / \mathrm{Al})$.

\subsection{Grain size}

Grain size was measured on the terrigenous fraction of the sediment of core JPC14 using a Coulter LS200 laser grain size analyzer. To isolate the terrigenous fraction, samples were treated with boiling $\mathrm{H}_{2} \mathrm{O}_{2}$ and $\mathrm{HCl}$, to remove organic matter and eventual carbonates, respectively. No diatoms were observed, so no alkaline treatment was applied. Prior to analysis, samples were boiled with $300 \mathrm{mg}$ of sodium pyrophosphate $\left(\mathrm{Na}_{4} \mathrm{P}_{2} \mathrm{O}_{7} \cdot 10 \mathrm{H}_{2} \mathrm{O}\right)$ to ensure complete disaggregation of the particles. The grain size distribution of the samples was measured during $90 \mathrm{~s}$ intervals and the arithmetic mean was calculated from the 92 size classes. Analyses were made every $8 \mathrm{~cm}$, except between 0 and $2 \mathrm{~m}$ and between 8 and $12 \mathrm{~m}$, where the sampling step was increased to 2 and $4 \mathrm{~cm}$, respectively. Sorting $\left(\sigma_{1}\right)$ was calculated according to Folk and Ward (1957).

\subsection{Bulk organic geochemistry}

Approximately $50 \mathrm{mg}$ of ground sediment samples of both cores was weighed in tin capsules, treated with $1 \mathrm{~N}$ sulphurous acid to remove eventual carbonates (Verardo et al., 1990) and analyzed at the UCDavis Stable Isotope Facility. Total Organic Carbon (TOC), Total Nitrogen (TN) and stable isotopic ratios of sedimentary carbon $\left(\delta^{13} \mathrm{C}\right)$ and nitrogen $\left(\delta^{15} \mathrm{~N}\right)$, were measured by continuous flow isotope ratio mass spectrometry (CF-IRMS; 20-20 SERCON mass spectrometer) after sample combustion to $\mathrm{CO}_{2}$ and $\mathrm{N}_{2}$ at $1000^{\circ} \mathrm{C}$ in an online elemental analyzer (PDZEuropa ANCA-GSL). The working standards, which are periodically calibrated against international isotope standards (IAEA N1, N3; IAEA CH7, NBS22), were a mixture of ammonium sulfate and sucrose with $\delta^{15} \mathrm{~N}$ vs. Air $=1.33 \%$ and $\delta^{13} \mathrm{C}$ vs. $\mathrm{PDB}=-24.44 \%$. The precision, calculated by replicate analysis of the internal standard, is $0.05 \%$ for $\delta^{13} \mathrm{C}$ and $0.28 \%$ for $\delta^{15} \mathrm{~N}$. The proportions of terrestrial and aquatic organic carbon were calculated from the N/C atomic ratios (Perdue and Koprivnjak, 2007), using end-member values of 0.130 and 0.0624 for aquatic and terrestrial organic matter, respectively (Bertrand et al., 2012).

\subsection{Carbonate content}

The weight percentage of total inorganic carbon (TIC) in bulk sediment samples of core JPC14 was determined using an UIC CM5012 coulometer equipped with a CM5130 acidification module. For each sample, 50-60 mg of sediment was precisely weighed into a Teflon cup, which was subsequently inserted into a glass tube and treated with $5 \mathrm{ml}$ $\mathrm{H}_{3} \mathrm{PO}_{4} 20 \%$ to liberate $\mathrm{CO}_{2}$. The percentage of carbonate 
Table 1. Radiocarbon ages obtained on sediment cores JPC14 and PC27.

\begin{tabular}{|c|c|c|c|c|c|c|c|}
\hline $\begin{array}{l}\text { Core depth } \\
(\mathrm{cm})\end{array}$ & $\begin{array}{l}\text { Laboratory } \\
\text { code }\end{array}$ & Material & $\delta^{13} \mathrm{C}(\% o)$ & $\begin{array}{l}{ }^{14} \mathrm{C} \text { yr BP } \\
\pm 1 \sigma\end{array}$ & $\begin{array}{c}\text { Reservoir } \\
\text { correction } \\
\quad(\mathrm{yr})\end{array}$ & $\begin{array}{r}2 \sigma \text { range calibrated } \\
\text { ages (cal yr BP) }\end{array}$ & $\begin{array}{r}\text { Weighted } \\
\text { average } \\
\text { (cal yr BP) }\end{array}$ \\
\hline \multicolumn{8}{|l|}{ Core JPC14 } \\
\hline 200 & OS-51044 & Shell fragments & 0.24 & $730 \pm 40$ & 480 & $140-327(89.2 \%)$ & 224 \\
\hline 210.75 & OS-79111 & Leaf & -28.37 & $120 \pm 25$ & - & $3-254(95.4 \%)$ & 101 \\
\hline 217 & OS-51079 & Leaf fragments & -29.52 & $230 \pm 25$ & - & $147-303(95.4 \%)$ & 208 \\
\hline 464 & OS-70902 & Shell fragments & 2.44 & $910 \pm 30$ & 480 & $328-507(95.4 \%)$ & 440 \\
\hline 559 & OS-51080 & Leaf fragments & -27.43 & $600 \pm 35$ & - & $513-634(95.4 \%)$ & 568 \\
\hline 690.5 & OS-51040 & Shell & -0.02 & $1240 \pm 45$ & 480 & $563-730(95.4 \%)$ & 653 \\
\hline 720.75 & OS-79113 & Twigs & -28.01 & $880 \pm 25$ & - & $685-791(95.4 \%)$ & 743 \\
\hline 1234 & OS-71182 & Shell fragments & 0.10 & $4590 \pm 25$ & 480 & $4423-4788(95.3 \%)$ & 4543 \\
\hline 1412.5 & OS-71183 & Shell fragments & -1.56 & $5000 \pm 20$ & 480 & $4972-5286(95.4 \%)$ & 5137 \\
\hline 1414 & OS-70903 & Shell fragments & -1.41 & $4980 \pm 35$ & 480 & $4876-5285(95.4 \%)$ & 5089 \\
\hline \multicolumn{8}{|l|}{ Core PC27 } \\
\hline 37.5 & OS-55891 & Twig & -27.06 & $280 \pm 100$ & - & $-2-491(95.4 \%)$ & 266 \\
\hline 68.25 & OS-52977 & Twig & -26.48 & $230 \pm 25$ & - & $146-304(95.4 \%)$ & 208 \\
\hline
\end{tabular}

was calculated from the TIC data using the following equation: $\mathrm{CaCO}_{3}(\mathrm{wt} \%)=\mathrm{TIC}(\mathrm{wt} \%) \times 8.33$. This method assumes that $100 \%$ of the measured $\mathrm{CO}_{2}$ is derived from dissolution of calcium carbonate. The limit of detection was $0.04 \% \mathrm{CaCO}_{3}$.

\subsection{Magnetic susceptibility}

Volume magnetic susceptibility (MS) was measured at $1 \mathrm{~cm}$ resolution $(0.5 \mathrm{~cm}$ on core $\mathrm{PC} 27)$ with a Bartington MS2E single-frequency $(2 \mathrm{kHz})$ sensor, connected to a Bartington MS2 meter.

\subsection{Seismic reflection}

A previously-published dense grid ( $~ 68 \mathrm{~km})$ of $3.5 \mathrm{kHz}$ subbottom seismic profiles (Fernandez et al., 2012) was used to discuss the lateral variability of the lithological units described in core JPC14. Methodological details are described in Fernandez et al. (2012). Briefly, the seismic data were obtained with a Bathy2000 sub-bottom profiler system, recorded digitally, and several seismic units were defined based on the amplitude and the frequency of the reflectors. The vertical resolution of the $3.5 \mathrm{kHz}$ seismic profiles is 20$30 \mathrm{~cm}$ so only the sedimentary units thicker than $\sim 50 \mathrm{~cm}$ can be accurately detected and mapped. Sediment core JPC14 was projected on seismic profiles using a p-wave velocity of $1500 \mathrm{~m} \mathrm{~s}^{-1}$.

\subsection{Historical data}

Colonial and republican bibliographic sources from the 1719th centuries were collected and analyzed to reconstruct recent variations in the ice front of Gualas glacier. Only original iconographic and text documents were used. The historical information related to Gualas glacier or Caleta Gualas was extracted with the help of specialized dictionaries (Pagés, undated; Corominas, 1976) to determine the meaning of epoch-specific concepts used by the explorers. The documented positions of Gualas glacier were superimposed on a false colour (green, red and near-infrared bands) Landsat image (16 February 2010), which was also used to determine the most recent position of the ice front.

\section{Results}

\subsection{Lithology}

Core JPC14 is composed of 3 main lithological units separated by gradual transitions (Fig. 2). The sediment is composed of grayish olive and mainly homogenous mud at $1500-1109 \mathrm{~cm}$ (Unit A) and at 740-0 cm (Unit C), and of olive black sand between 1086 and $800 \mathrm{~cm}$ (Unit B). Sediment of all intermediate grain sizes, from silty mud to silty sand, composes the gradual transitions between units $\mathrm{A}-\mathrm{B}$ $(1109-1086 \mathrm{~cm})$ and $\mathrm{B}-\mathrm{C}(800-740 \mathrm{~cm})$ (Fig. 2). In addition, twelve thin (5 to $30 \mathrm{~mm}$ ) silt layers, sometimes showing fining-upward structures, were observed intercalated in Unit $C$ between 197 and $65 \mathrm{~cm}$ (Unit $C^{\prime}$ ). Organic debris dispersed in the sediment occur at $731-718 \mathrm{~cm}$ and at 234 $204 \mathrm{~cm}$ (Fig. 2). Two sandy layers, interpreted as rhyolitic and basaltic tephras, were observed at 1473-1474.5 and 21$22 \mathrm{~cm}$, respectively. Core PC27 is entirely composed of homogeneous mud. Eight silt layers are intercalated between 72 and $132 \mathrm{~cm}$, and a dark silt layer, which was interpreted as a tephra, occurs between 39 and $37.5 \mathrm{~cm}$. 


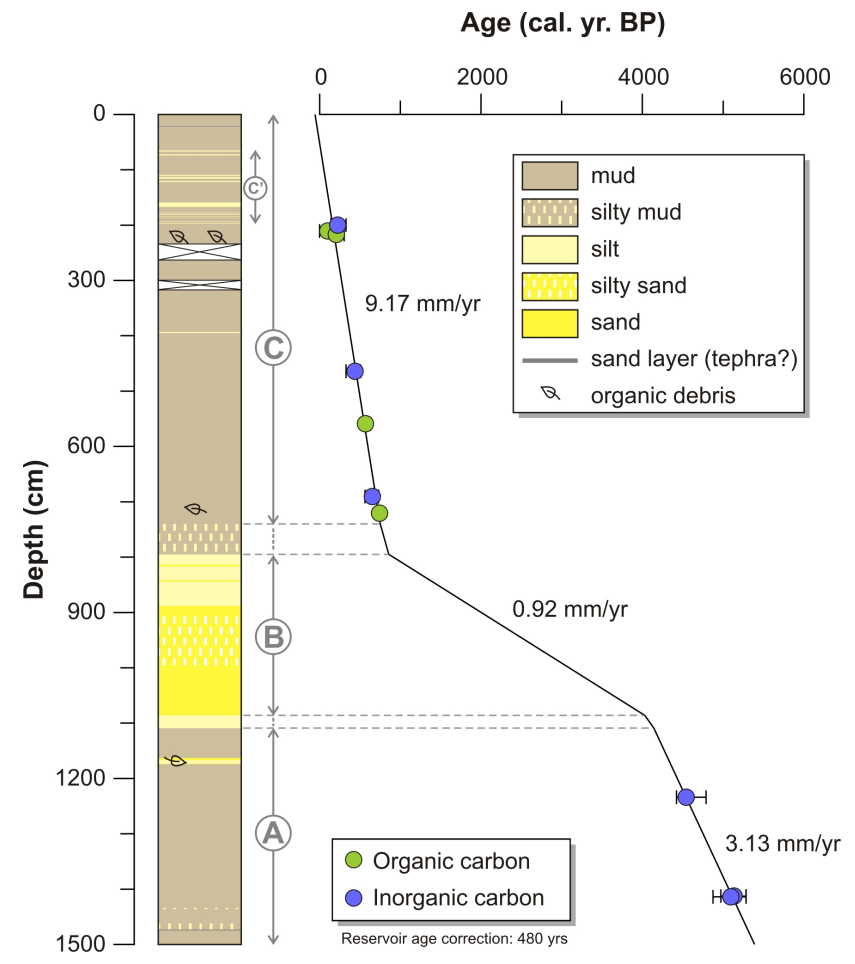

Fig. 2. Lithology and age model of sediment core JPC14. Most of the dots are larger than the error bar that represents the $2 \sigma$ range of the calibrated ages. The circled letters refer to the main lithological units discussed in the text (see Sect. 4.1). Radiocarbon ages are listed in Table 1.

The bulk composition of the sediment of core JPC14 is clearly dominated by lithogenic particles. The TOC is low $(0.62 \pm 0.27 \%)$, the carbonate content is always below limit of detection and only a very few diatoms (always $<3$ vol. \%) were observed in smear slides. The water content of the sediment (not shown) reflects the lithology, with values of 20 $30 \%$ for the coarse units $B$ and $C^{\prime}$, and around $40-45 \%$ for the mud units $\mathrm{A}$ and $\mathrm{C}$.

\subsection{Chronology}

The age model of sediment core JPC14 was constructed using the weighted average of the calibrated radiocarbon ages (Fig. 2). Two linear regressions were computed through the upper 7 and lower 3 samples. Between 1109 and $740 \mathrm{~cm}$, the age model was constructed by interpolation, considering changes in lithology as breakpoints (Fig. 2). The resulting age model is composed of 5 linear regressions, with sedimentation rates varying between $0.92 \mathrm{~mm} \mathrm{yr}^{-1}$ (Unit B) and $9.17 \mathrm{~mm} \mathrm{yr}^{-1}$ (Unit C). Core JPC14 covers the last $5400 \mathrm{yr}$. A possible basaltic tephra layer at $21-22 \mathrm{~cm}$ in core JPC14 and at $37.5-39 \mathrm{~cm}$ in core PC27 may correspond to the explosive eruption of Hudson volcano in 1971, which also deposited a tephra in lakes of Taitao Peninsula (Haberle and Lumley, 1998). According to our age model, the tephra layer observed at $1474 \mathrm{~cm}$ in core JPC14 has an age of 5300 cal yr BP. It is mainly composed of white sand grains, and it is of rhyodacitic composition (bulk sample analyzed by ICP-AES). Its radiocarbon age does not correspond to any known tephra in the region but since it is superposed by a thin fining-upward deposit, it may represent reworked material.

\subsection{Grain size, magnetic susceptibility and inorganic geochemistry}

The arithmetic mean grain size of the sediment in core JPC14 varies between 7.1 and $180.4 \mu \mathrm{m}$. The sediment is dominated by silt-size particles $(63.0 \pm 17.8 \%)$, but clay $(<2 \mu \mathrm{m})$ and sand $(>63 \mu \mathrm{m})$ particles occur in all samples (Fig. 3). The changes in lithology that were observed macroscopically are clearly reflected in the sand content, which varies between 0 and $80 \%$ (Fig. 3). The grain size data also display high concentrations of clay-size particles at $730-525 \mathrm{~cm}$, a coarsening-upward trend at $1350-1150 \mathrm{~cm}$, and a finingupward trend at $800-250 \mathrm{~cm}$. Most of the samples are very poorly sorted $\left(2<\sigma_{1}<4\right)$, with the highest $\sigma_{1}$ values (poorest sorting) occurring between 1000 and $650 \mathrm{~cm}$.

The magnetic susceptibility values (Fig. 3 ) are highly correlated to the mean grain size of the sediment $(r=0.74$, $p<0.001$; Table 2), as previously reported for surface sediment samples from the North Patagonian fjords (Bertrand et al., 2012). MS also clearly highlights the thin silt layers that occur in the upper section of Unit $\mathrm{C}$ (identified as $\mathrm{C}^{\prime}$ in Fig. 3). The MS profile of core PC27 matches the MS of core JPC14 (see Sect. 5.4), demonstrating that the signal observed in JPC14 is representative of the entire Golfo Elefantes.

$\mathrm{XRF} \mathrm{Zr}$ intensities and ICP-AES Zr/Al measurements are highly correlated to each other and to the sand content of the sediment (Table 2). This relation originates from the high refractoriness, and therefore coarse grain size, of zircon, in which $\mathrm{Zr}$ is concentrated (Bertrand et al., 2012). Similarly, $\mathrm{Si} / \mathrm{Al}$, which reflects the quartz content of the sediment (Bertrand et al., 2012), displays a strong positive correlation with grain size $(r=0.80, p<0.001)$.

\subsection{Bulk organic geochemistry}

TOC is low throughout core JPC14, with only a few samples containing TOC $>1 \%$ (Fig. 4). The organic carbon content of aquatic origin (aq OC; $0.18 \pm 0.10 \%$ ) is low compared to the organic carbon content of terrestrial origin (terr $\mathrm{OC}$; $0.44 \pm 0.22 \%$ ). Most of the downcore variability is due to changes in terr OC (Fig. 4). It is also clear that the samples corresponding to the coarse sedimentary units $\left(\mathrm{B}\right.$ and $\mathrm{C}^{\prime}$ ) are depleted in terrestrial carbon.

\subsection{Seismic profiling}

The three main lithological units described in sediment core JPC14 correspond well to the seismic units identified on seismic line 5 (Fig. 5). The upper seismic unit (G6; Fernandez 


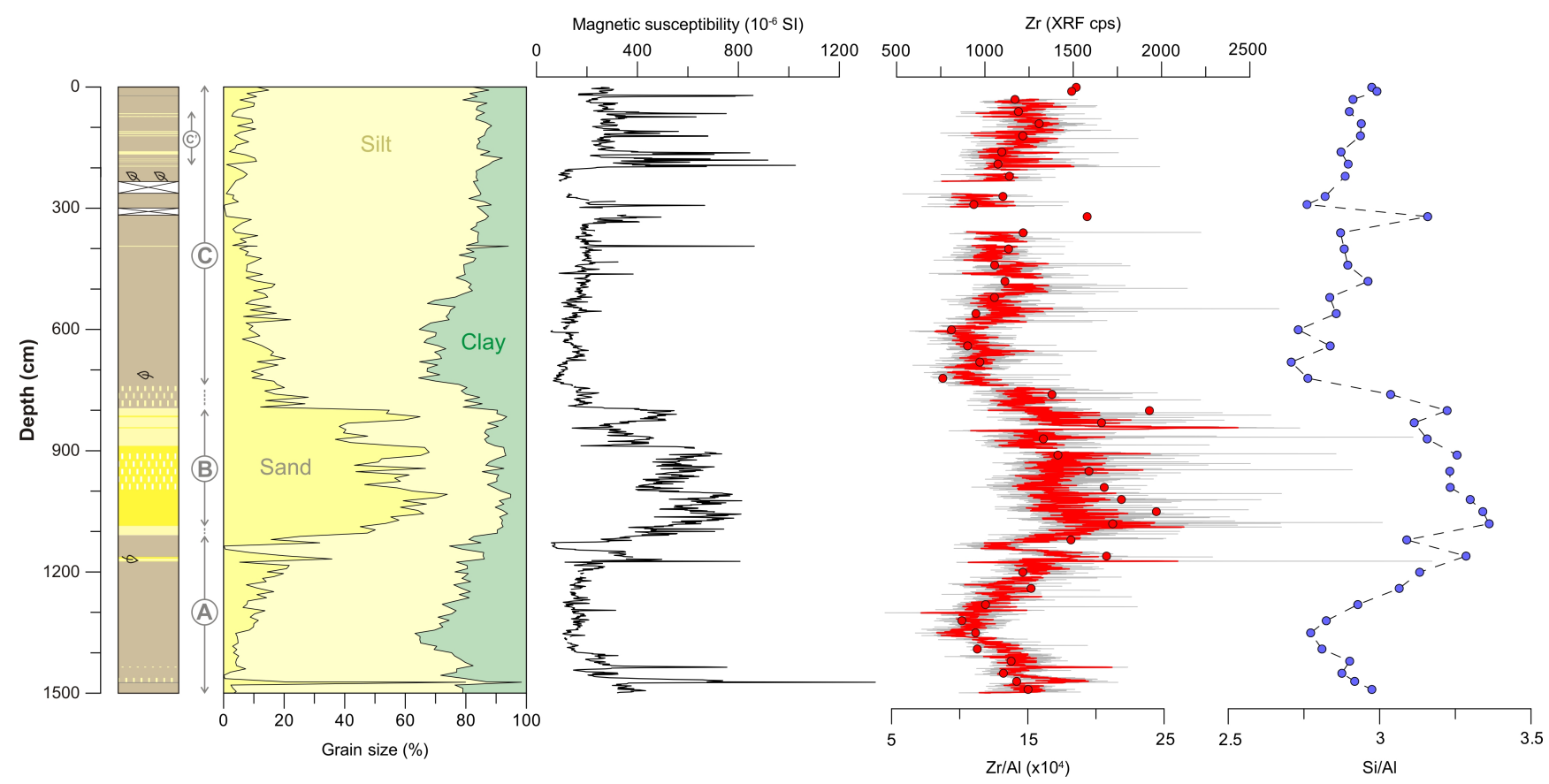

Fig. 3. Selected physical and geochemical proxies in sediment core JPC14 (grain size, magnetic susceptibility, Zr XRF core scanner counts, and $\mathrm{Zr} / \mathrm{Al}$ and $\mathrm{Si} / \mathrm{Al}$ elemental ratios).

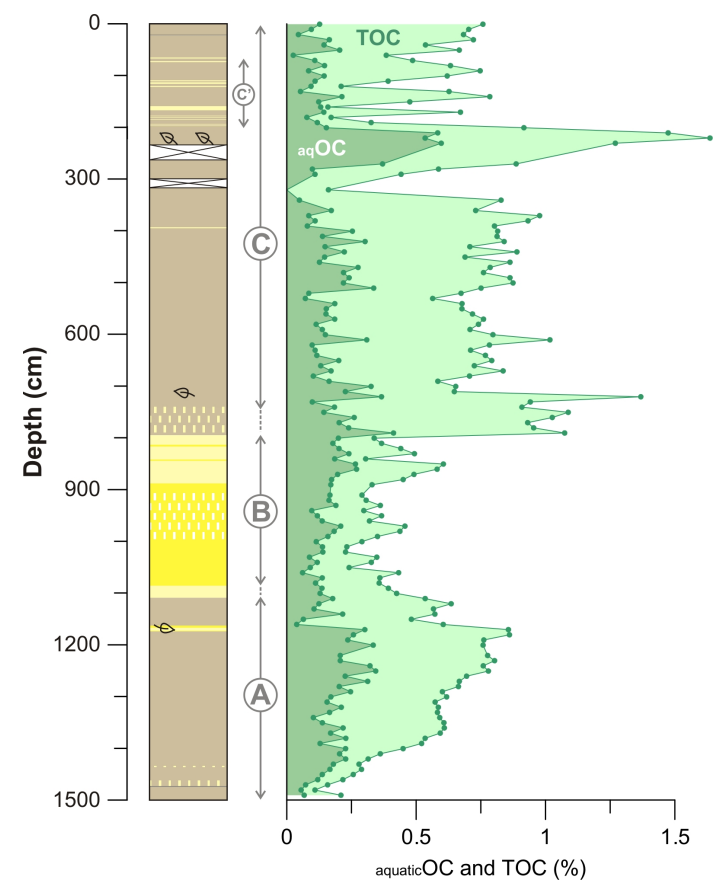

Fig. 4. Total Organic Carbon (TOC) and aquatic carbon (aq OC) of sediment core JPC14. et al., 2012) corresponds to the upper part of lithological Unit C. Seismic unit G5, which is acoustically transparent, corresponds to the mud-dominated unit that forms the lower part of lithological Unit C. Seismic unit G4 relates to the sand-dominated Unit B, and the upper part of seismic unit G3 corresponds to the lower mud unit A. Seismic profiles show that the thickness of these four units varies gradually and that all the cored lithological units occur across the entire basin. No seismic unit is restricted to the deepest part of the basin (Fernandez et al., 2012).

\subsection{Historical chronicles}

The first known historical record that mentions the glaciers and fjords of Northern Chilean Patagonia dates back to 1675 AD, when Spanish pilot Antonio de Vea traveled through the Patagonian channels to reach Laguna San Rafael via Golfo Elefantes and Rio Tempanos. His detailed report does not mention the presence of a glacier in Gualas valley. Similarly, no historical documents from the 17th, 18th and most of the 19th centuries, including Simpson (1875), makes mention of a glacier at this location. The first document to mention Gualas glacier is the report and map of geographer Hans Steffen (1910), following his expedition of NovemberDecember 1898. In his written document, Steffen clearly describes that Gualas glacier was reaching sea level in the bay called Caleta Gualas ("se nota un ventisquero que baja hasta el nivel del mar en un pequeño estero de la costa oriental del seno de Elefantes"). This written statement is confirmed 


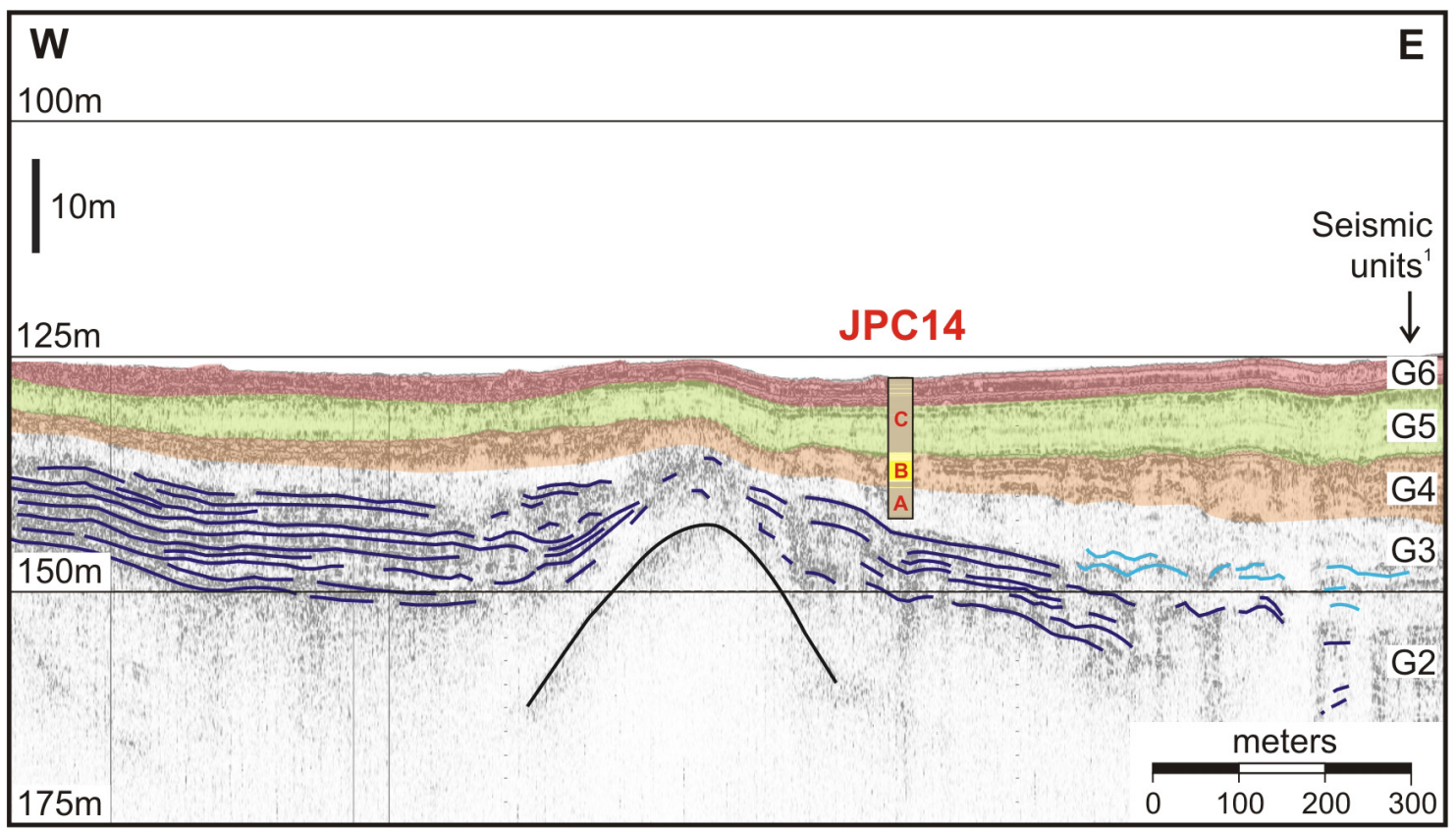

Fig. 5. High-resolution ( $3.5 \mathrm{kHz})$ seismic profile across JPC14 coring site (line 5, from Fernandez et al., 2012). Sediment core JPC14 was projected using a p-wave velocity in the sediment of $1500 \mathrm{~m} \mathrm{~s}^{-1}$. For location, see Fig. $1 .{ }^{1}$ From Fernandez et al. (2012).

Table 2. Pearson correlation matrix of selected variables measured on core JPC14. Only the 44 samples (1.5 cm thick) used for ICP-AES analysis were used. For variables that were measured at a resolution $<1.5 \mathrm{~cm}$ (XRF and MS), all the values corresponding to the $1.5 \mathrm{~cm}$ thick sample were averaged. Values in bold are different from 0 with $p<0.001$.

\begin{tabular}{|c|c|c|c|c|c|c|c|c|}
\hline & $\begin{array}{r}\text { Grain size } \\
(\text { mean })\end{array}$ & $\begin{array}{r}\text { Sand } \\
\text { content }\end{array}$ & $\mathrm{Si} / \mathrm{Al}$ (ICP) & $\mathrm{Zr} / \mathrm{Al}$ (ICP) & $\mathrm{Zr}(\mathrm{XRF})$ & $\begin{array}{r}\text { Magnetic } \\
\text { susc. }\end{array}$ & $\begin{array}{r}\text { Water } \\
\text { content }\end{array}$ & terr $\mathrm{OC}$ \\
\hline Grain size (mean) & 1 & 0.991 & 0.799 & 0.753 & 0.666 & 0.739 & -0.626 & -0.422 \\
\hline Sand content & 0.991 & 1 & 0.802 & 0.732 & 0.679 & 0.726 & -0.587 & -0.390 \\
\hline $\mathrm{Si} / \mathrm{Al}$ (ICP) & 0.799 & 0.802 & 1 & 0.906 & 0.808 & 0.742 & -0.681 & -0.426 \\
\hline $\mathrm{Zr} / \mathrm{Al}$ (ICP) & 0.753 & 0.732 & 0.906 & 1 & 0.769 & 0.702 & -0.683 & -0.399 \\
\hline $\mathrm{Zr}(\mathrm{XRF})$ & 0.666 & 0.679 & 0.808 & 0.769 & 1 & 0.738 & -0.535 & -0.394 \\
\hline Magnetic susc. & 0.739 & 0.726 & 0.742 & 0.702 & 0.738 & 1 & -0.835 & -0.706 \\
\hline Water content & -0.626 & -0.587 & -0.681 & -0.683 & -0.535 & -0.835 & 1 & 0.793 \\
\hline terr $\mathrm{OC}$ & -0.422 & -0.390 & -0.426 & -0.399 & -0.394 & -0.706 & 0.793 & $\mathbf{1}$ \\
\hline
\end{tabular}

by the location of Gualas glacier on the map that represents his journey through the fjords (Fig. 6a), and by subsequent reports of the same expedition (Steffen, 1919, 1947). In his 1947 document, for example, he mentions that in 1898 Gualas glacier advanced very close to the beach of Caleta Gualas ("en su [bahia guata] interior se puede observar el primer ventisquero de los campos de hielo del Cerro San Valentín, que avanza hasta las proximidades inmediatas de la playa").

A second important historical document is the aerial photograph of US Air Force "Trimetrogon" flight in 1944. The photograph (Fig. 6b) shows that in 1944, the ice front of Gualas glacier was located at the northwestern end of its present-day proglacial lake. Aerial photographs of January 1986 show Gualas glacier front located $600 \mathrm{~m}$ behind its 1944 position (Aniya, 1988).

Compared to the 2010 front position (Fig. 6c), the ice front was $8.9 \mathrm{~km}$ more advanced in $1898,3.4 \mathrm{~km}$ more advanced in 1944, and $2.8 \mathrm{~km}$ more advanced in 1985 , which demonstrates that Gualas glacier retreated by $5.5 \mathrm{~km}$ between 1898 and $1944\left(120 \mathrm{~m} \mathrm{yr}^{-1}\right)$, by $600 \mathrm{~m}$ between 1944 and $1985\left(15 \mathrm{~m} \mathrm{yr}^{-1}\right)$ and by $2.8 \mathrm{~km}$ between 1985 and 2010 $\left(112 \mathrm{~m} \mathrm{yr}^{-1}\right)$. This represents a retreat of $8.9 \mathrm{~km}$ and a surface area loss of $10.8 \mathrm{~km}^{2}$ between 1898 and 2010 . 

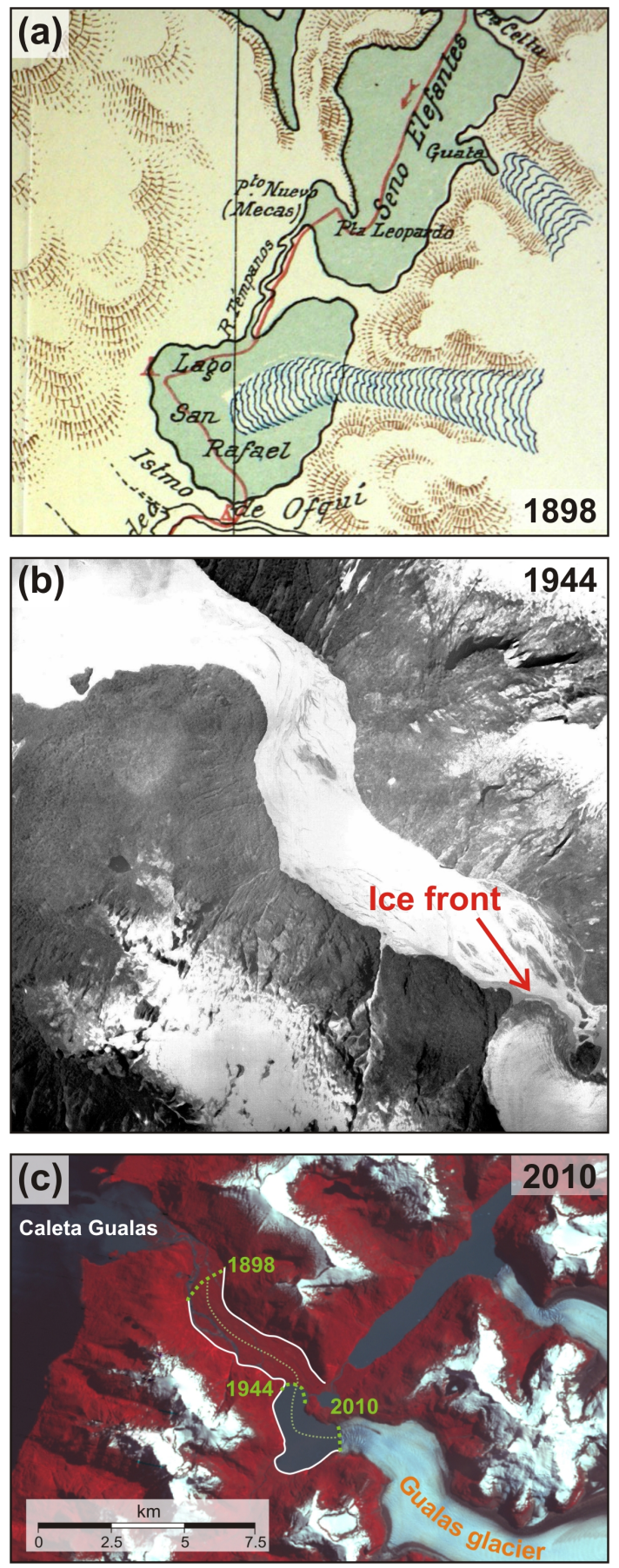

Fig. 6. Historical positions of Gualas glacier. (a) Map of Steffen (1910), summarizing his observations of 1898. (b) Aerial photograph of Trimetrogon flight in 1944. (c) False color Landsat 2010 image, with indications of the ice front position of Gualas glacier in 2010, 1944 and 1898, according to (a) and (b). The white line delimits Gualas glacier valley and it was used to calculate the surface area loss. The dashed line represents the central path of Gualas glacier, as it was used to calculate length variations.

\section{Interpretation and discussion}

\subsection{Sedimentary processes}

The two fine-grained units $\mathrm{A}$ and $\mathrm{C}$ contain a low percentage of sand (Fig. 3) and their grain size distributions are typical of proglacial river sediments (Fig. 7), which are generally dominated by silt-size particles between 6 and $20 \mu \mathrm{m}$ (Fenn and Gomez, 1989; Haritashya et al., 2010). This observation is in agreement with the present-day setting of Golfo Elefantes, where the sediment is supplied by the $8 \mathrm{~km}$ long proglacial Gualas river. These two sedimentary units are relatively rich in terrestrial organic carbon (Fig. 4), which demonstrates the presence of vegetation in the catchment (see also Fig. 1b). They were deposited rapidly between 5400 and $4130 \mathrm{cal}$ yr BP and after $750 \mathrm{cal}$ yr BP (accumulation rates of 3.13 and $9.17 \mathrm{~mm} \mathrm{yr}^{-1}$, respectively). They most likely represent sedimentary conditions similar to the present environment, with the Gualas proglacial river discharging mud particles in Golfo Elefantes. The high accumulation rates most likely result from the reworking of freshly exposed glacial deposits by the proglacial fluvial system. This process is particularly important in actively retreating environments (Lemmen et al., 1988; Szczuciński et al., 2009).

Lithological unit B is dominated by fine to coarse sand (Fig. 3), although its grain size distribution shows that it also contains significant amounts of silts and clays (Figs. 3 and 6). It does not contain particles coarser than $1 \mathrm{~mm}$ (i.e. no drop stones). This unit does not present any macroscopical sedimentary structures. It is very poor in terrestrial organic carbon and it does not contain any carbonate shell remains. Its estimated average accumulation rate is much lower than for units $\mathrm{A}$ and $\mathrm{C}\left(0.92 \mathrm{~mm} \mathrm{yr}^{-1}\right)$, and our age model suggests that it was deposited between 4020 and 850 cal yr BP (Fig. 2). Such a sedimentary unit does not represent sediment transported by a typical proglacial river, but could result from (1) winnowing of the fine-grained particles, or (2) a change in the sediment source(s) and erosion processes. The presence of significant amounts of silt and clay-size particles tends to refute the winnowing hypothesis. The coarse particles could however originate from several reworked proglacial environments: proglacial lakes, outwash fans, proglacial deltas, and moraines. Two arguments are in favor of a reworking of previously deposited fan/deltaic sediments during an advance of Gualas glacier: the presence of a Holocene moraine immediately in front of Gualas river (MSIII, Fig. 1b), and the rapid historical fluctuations of Gualas glacier (see Sect. 4.6 above). This interpretation is also in agreement with the very poor sorting of this unit, the absence of carbonate shells and the very low terr $\mathrm{OC}$ of the unit. The presence of an $11 \mathrm{~cm}$ thick turbidite containing terrestrial organic matter debris at $1170 \mathrm{~cm}$ (Fig. 3) may represent the erosion of a proglacial lake that existed in the valley of Gualas river at the beginning of the advance. The low accumulation rate of this unit likely represents the absence of a large proglacial fluvial system 
(i.e. a glacier in an advanced position) and/or a relatively stable ice front.

It is important to mention that unit B cannot be regarded as a large turbidite since (1) its grain size profile does not show the typical fining-upward trend (Fig. 3), (2) unit B occurs in most of the basin and its thickness does not increase in the deepest part of the basin (Fernandez et al., 2012), (3) no erosive contact was observed, and (4) unit B corresponds to strong seismic reflectors (turbidites are generally transparent in seismic profiles; e.g. Hieke, 2000; Volland et al., 2007).

The two transitions (A-B at 1109-1086, and B-C at 800$740 \mathrm{~cm}$ ) represent gradual evolutions from one lithology to the next. The A-B transition is marked by a rapid increase in sand-size particles, which could represent the scouring of a pro-glacial lake or of a proglacial fluvial plain. The B-C transition, on the other hand, is characterized by an increase in clay-size particles, which most likely represents an evolution towards a fluvio-glacial mode of sediment transport during a retreat of Gualas glacier.

Finally, the twelve thin silt layers that occur in unit $\mathrm{C}^{\prime}$ (197-14 cal yr BP, i.e. $\sim 1750-1935$ AD) may represent secondary advances of Gualas and/or Reicher glaciers, that drained their proglacial lakes and supplied silt-size particles to Golfo Elefantes.

Although changes in sedimentation through the Holocene could also be affected by variations in river discharge resulting from direct changes in precipitation rates, we believe that most of the observed variations represent fluctuations of Gualas ice front position and the development of proglacial lakes in the drainage basin. This statement is mainly based on the observation that the watershed of Golfo Elefantes, i.e. the drainage area of Gualas river, is currently $66 \%$ covered by Gualas and Reicher glaciers. Since the glacier cover was either similar or higher during the Holocene, the sedimentary processes must have been chiefly controlled by glacier variability. On shorter time-scales, sporadic processes such as migration of the fluvial network or remobilization of unused sediment sources could also account for changes in sedimentation.

\subsection{Gualas glacier variability during the last $5400 \mathrm{yr}$}

If the above interpretation is correct, our results suggest that Gualas ice front was close to its present-day position (i.e. inland with a proglacial fluvial system) between 5400 and $4130 \mathrm{cal} \mathrm{yr} \mathrm{BP}$, and since $750 \mathrm{cal}$ yr BP. It also suggests that Gualas glacier reached the shore of Golfo Elefantes between 4020 and $850 \mathrm{cal}$ yr BP, and that it was affected by secondary fluctuations between 1750 and $1935 \mathrm{AD}$. The major glacier advance at 4020-850 cal yr BP would be responsible for the formation of moraine MSIII in Caleta Gualas, which is visible in aerial and submarine morphology (Figs. 1 and 6). Under this scenario, the ice front would have retreated by $\sim 10 \mathrm{~km}$ during the last $900 \mathrm{yr}$. While this may appear as a large fluctuation, this interpretation is supported by historical

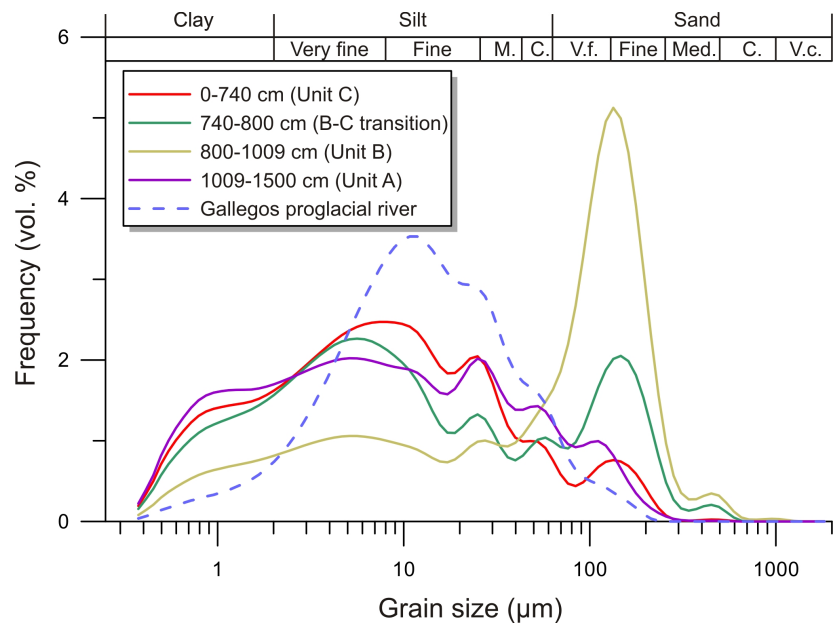

Fig. 7. Average grain size distributions of the main lithological units in core JPC14, compared to the grain size distribution of a sample of suspended particles collected in the proglacial Gallegos river (Southern Patagonian Icefield, $54.513^{\circ} \mathrm{S}-69.871^{\circ} \mathrm{W}$ ). The latter is representative of proglacial river sediments (Fenn and Gomez, 1989; Haritashya et al., 2010). The distributions demonstrate that lithological units A $(1500-1009 \mathrm{~cm})$ and C $(740-0 \mathrm{~cm})$ are typical of proglacial sediments.

documents, which show that rapid $\left(>100 \mathrm{~m} \mathrm{yr}^{-1}\right.$ ) fluctuations of Gualas glacier were frequent during the last century.

This general interpretation of Gualas glacier fluctuations during the mid- and late- Holocene is represented in Fig. 8, which uses the high-resolution magnetic susceptibility and grain size results. In addition to showing the three main periods mentioned above, this figure also suggests that the advance of Gualas glacier could have started as early as 4800 cal yr BP (minor increase in grain size), and that the $4180-850$ cal yr BP period can be subdivided into three subperiods. These sub-periods may represent three cycles of secondary advance-retreat variations of an already advanced Gualas glacier.

\subsection{Comparison with moraine chronology}

In this section, we compare our record of Gualas glacier fluctuations, which constitutes the first continuous midand late-Holocene record of fluctuations of an NPI outlet glacier, to previously published results of maximum Neoglacial advances of Southern Patagonian glaciers (Fig. 8). The chronology of Holocene glacier variability in Patagonia is almost exclusively based on radiocarbon ages obtained on organic deposits in and around frontal moraines of outlet glacier of the SPI (Mercer, 1970, 1976, 1982; Aniya, 1995, 1996). These data, which are thoroughly summarized in Glasser et al. (2004), demonstrate the absence of early Holocene glacier advances and three or four advances after $5000{ }^{14} \mathrm{C}$ yr BP $(\sim 5700 \mathrm{cal} \mathrm{yr} \mathrm{BP})$. Two models of Neoglacial advances 

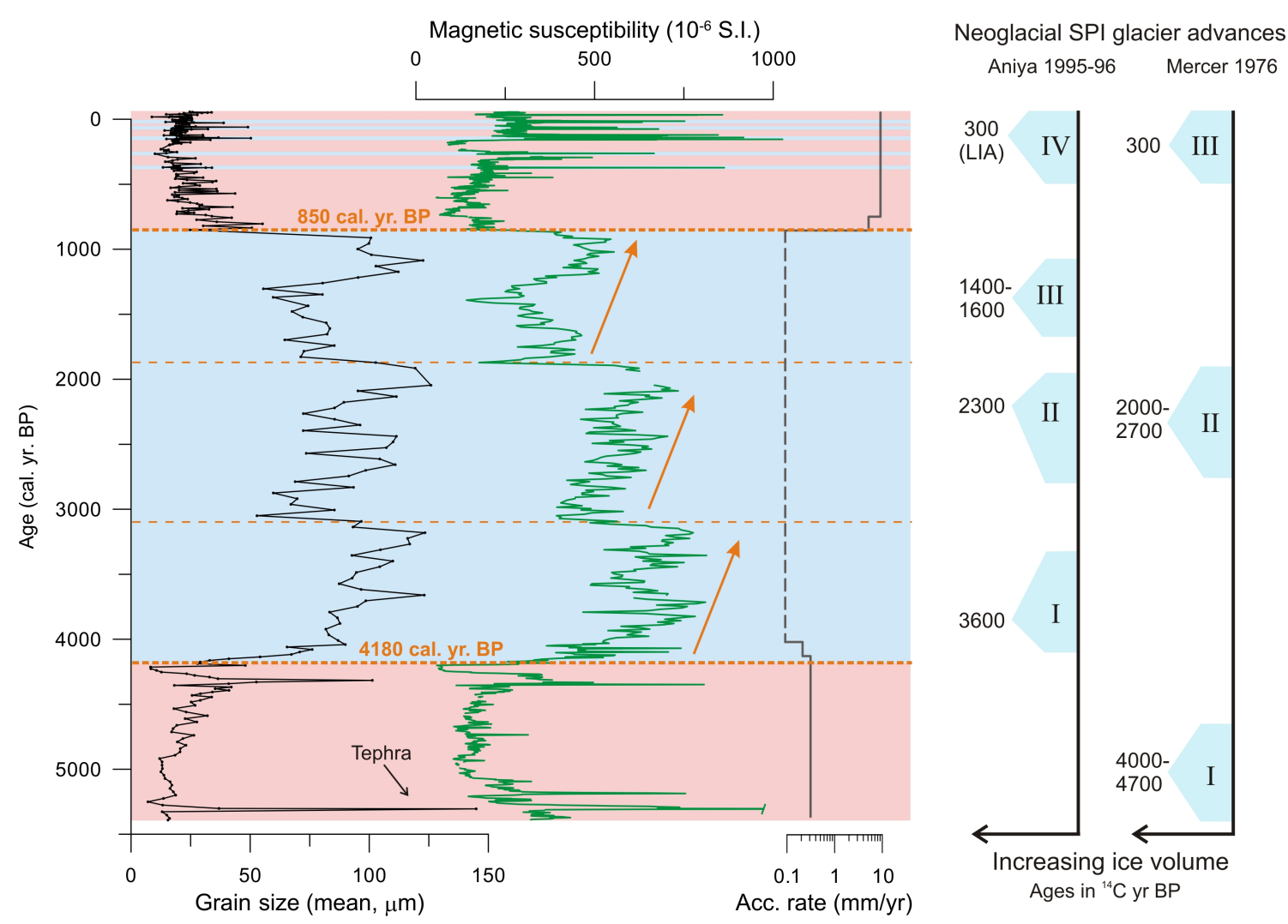

Fig. 8. Mean grain size, magnetic susceptibility and average accumulation rates of sediment core JPC14 plotted against age. The colors in the background represent the interpretation of the proxy variations (blue: glacier advance, pink: glacier retreat). The Mercer and Aniyatype chronologies of Neoglacial advances of SPI glaciers are indicated for comparison (Mercer, 1976, 1982; Aniya, 1995, 1996). The accumulation rate between 4020 and $850 \mathrm{cal} \mathrm{yr} \mathrm{BP}$ is represented by a dashed line to indicate possible changes in accumulation rates not identified in our age-model. The representation of the SPI glacier fluctuations was inspired by the Fig. 4 of Glasser et al. (2004).

were proposed: the Mercer-type chronology, with glacier advances at $4700-4000{ }^{14} \mathrm{C}$ yr BP $(\sim 5400-4400$ cal yr BP $)$; 2700 to $2000{ }^{14} \mathrm{C}$ yr BP $(\sim 2750-1900$ cal yr BP) and during the last three centuries (Mercer, 1976, 1982), and the Aniya-type chronology, with advances at $3600{ }^{14} \mathrm{C} \mathrm{yr} \mathrm{BP}$ $(\sim 3850$ cal yr BP $), 2300{ }^{14} \mathrm{C}$ yr BP $(\sim 2200$ cal yr BP $), 1600$ $1400{ }^{14} \mathrm{C}$ yr BP $(\sim 1450-1300$ cal yr BP $)$ and again during the last three centuries (Aniya, 1995, 1996) (Fig. 8).

No such model exists for the NPI but it is generally assumed that NPI glaciers followed the same chronology. This argument is supported by the radiocarbon age of the bottom of a small lake located on top of the outermost (oldest) Tempanos moraine, in front of San Rafael glacier (4000 ${ }^{14}$ C BP, Heusser, 1960), which seems to be in agreement with the first Neoglacial advance proposed by Mercer. However, this only gives a minimal age and the moraine, which has traditionally been considered to mark the onset of Neoglaciation in the southern Andes, could be much older. In the valley of Rio Quetro, Mardones et al. (2011) identified a frontal moraine dated at $2.250 \pm 40 \mathrm{BP}$ (23402150 cal yr BP), in agreement with Neoglacial advance II of Mercer $(1970,1976,1982)$ and Aniya $(1995,1996)$. On the eastern side of the Andes, Harrison et al. (2008) demonstrated that León glacier retreated from a large terminal moraine about $2500 \mathrm{yr}$ ago, using four complementary dating techniques (cosmogenic isotopes, OSL, dendrochronology and lichenometry). Therefore, this moraine could also represent Neoglacial advance II, which may have been the largest in the region.

Our sedimentary record of Gualas glacier variability is in excellent agreement with the Aniya-type chronology (Fig. 8). The three advance/retreat cycles of Gualas glacier between $\sim 4180$ and 850 cal yr BP correspond remarkably well to Neoglacial advances I, II and III of Aniya (1995, 1996). In addition, the silt layers that occur between 1750 and $1940 \mathrm{AD}$, which we interpret as secondary fluctuations of Gualas glacier during the last $300 \mathrm{yr}$, coincide with the last Neoglacial advance (Little Ice Age, LIA) of Mercer (1976) and Aniya (1995, 1996). Our sedimentological data are therefore in very good agreement with the chronology of SPI outlet glaciers, but also with the results of Harrison et al. (2008) and Mardones et al. (2011) for the NPI. 


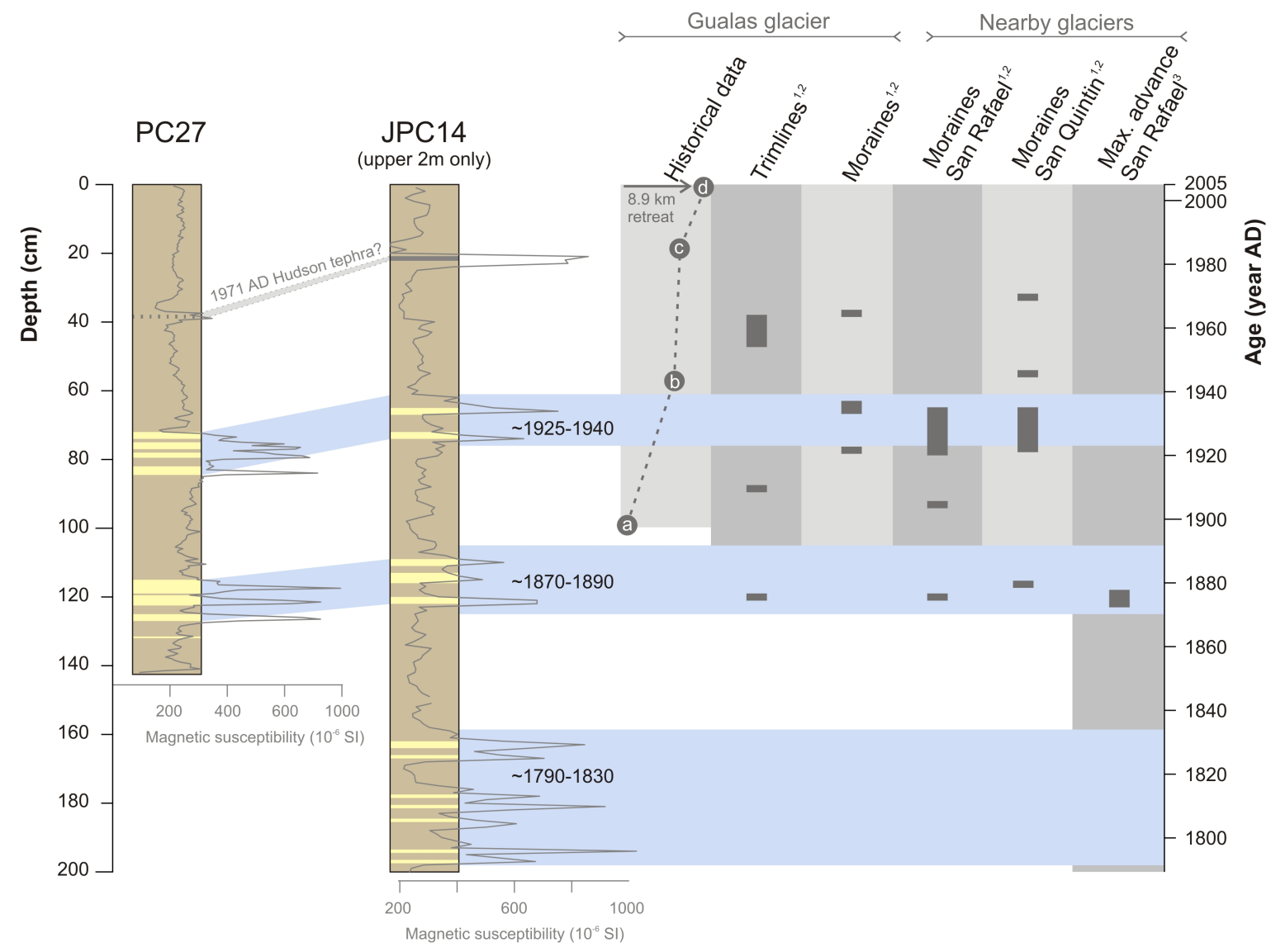

Fig. 9. Lithology and magnetic susceptibility (MS) of sediment core PC27 and of the upper $2 \mathrm{~m}$ of core JPC14. The results show the presence of several thin silt layers characterized by high MS values at $\sim 1790-1830$ AD, 1870-1890 AD, 1925-1940 AD. No such silt layers occur below $2 \mathrm{~m}$ depth. The lithological legend is indicated in Fig. 2 and the age scale corresponds to core JPC14. The right-hand side of the figure summarizes the historical and previously-published results that document recent fluctuations of Gualas and nearby glaciers. For Gualas glacier, the historical data are from: (a) Steffen (1910); (b) Trimetrogon flight (1944); (c) Aniya (1988); (d) Landsat (2010). Previously-published results are from: ${ }^{1}$ Harrison and Winchester (1998); ${ }^{2}$ Harrison et al. (2007); ${ }^{3}$ Araneda et al. (2007). The length of the vertical gray areas represents the maximum length of the records.

\subsection{Comparison with historical and dendrochronological data}

According to our interpretation of sediment core JPC14, Gualas glacier was entirely land-based after 850750 cal yr BP (1300-1200 AD). Our record also suggests the presence of three short periods of rapid glacier advance-retreat between 1750 and $1935 \mathrm{AD}$ (Fig. 9): 1790-1830 AD, 1870-1890 AD and 1925-1940 AD. Two of these three episodes are also well expressed in sediment core PC27 (Fig. 9).

Historical records confirm that Gualas glacier was landbased during at least the last $114 \mathrm{yr}$ and that the ice front in $1898 \mathrm{AD}$ was $8.9 \mathrm{~km}$ more advanced than at present. The fact that early Spanish explorers (16-19th centuries) do not mention Gualas glacier likely means that the glacier could not be seen from Golfo Elefantes, which supports our interpretation that Gualas glacier was land-based for the last few centuries.
By comparison, the explorers that sailed through the fjords of Northern Patagonia provided detailed descriptions of the nearby San Rafael glacier, which was either reaching the eastern rim of the Lagoon, or was floating on it during the last $435 \mathrm{yr}$. Using a detailed analysis of historical documents, Araneda et al. (2007) demonstrated that the maximum historical advance of San Rafael glacier occurred in 1875 AD, which they relate to its maximum LIA advance.

Dendrochronological data obtained on moraines and trimlines of glaciers Gualas, Reicher, San Quintin, and San Rafael are in agreement with a general retreat of NPI western outlet glaciers during the 1870s (Harrison and Winchester, 1998). These authors also observed marked retreats during the 1920s-1930s and 1960s-1970s (Fig. 9).

Our results are in good agreement with the major expansion of San Rafael glacier in 1875 AD, and with the formation of moraines and trimlines in front of Gualas, San Rafael, 


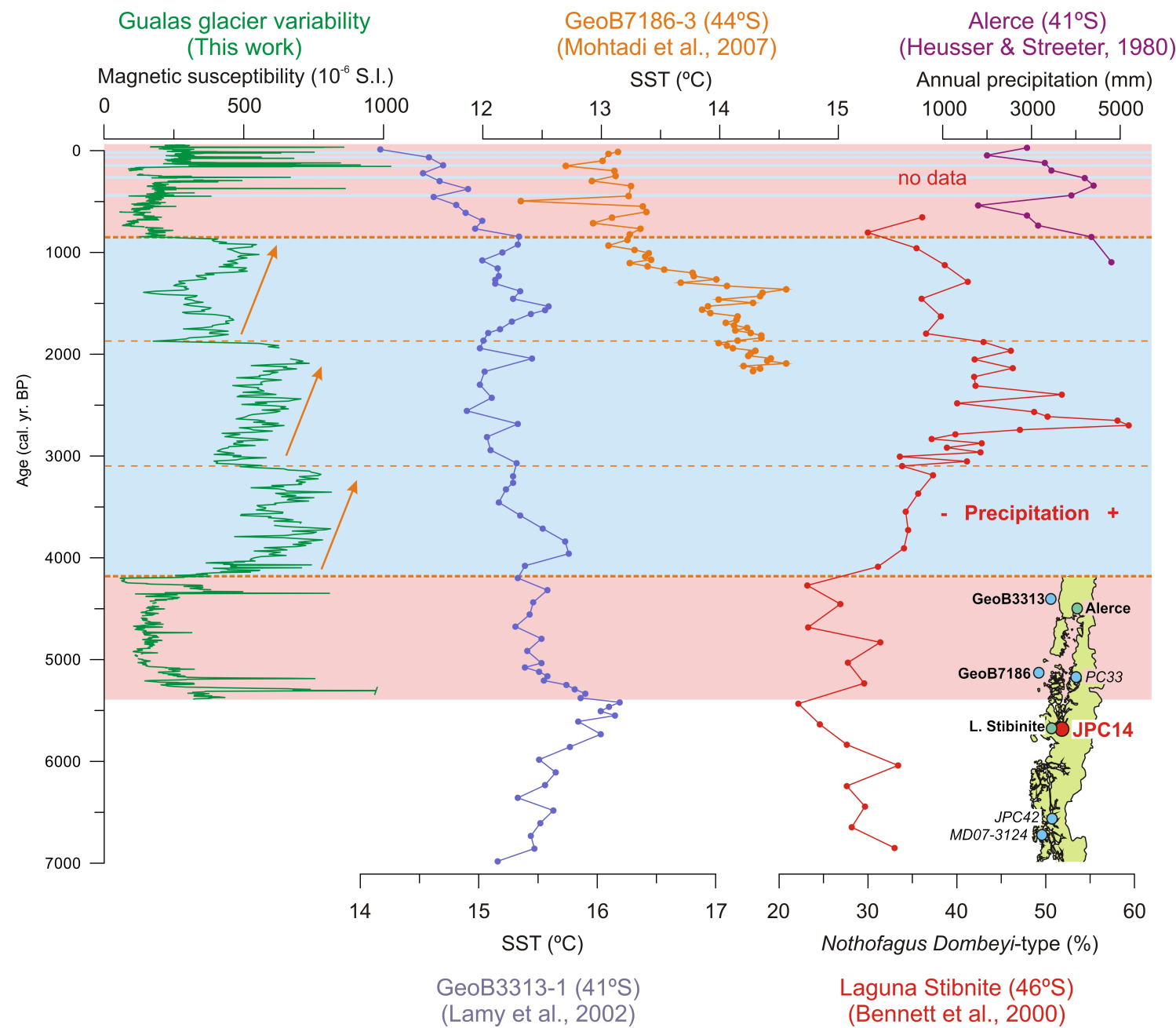

Fig. 10. Comparison of the magnetic susceptibility record of sediment core JPC14 with regional SST and precipitation records. The upper part of the pollen-derived precipitation record of Heusser and Streeter (1980) is represented to complement the Laguna Stibnite record during the last millennium. The rest of the Alerce pollen record of Heusser and Streeter (1980) is not represented because of (1) a weak chronology, (2) the relatively low resolution of the record, and (3) the unavailability of the raw data. Inset: location of the records used in this figure and discussed in the text, on a simplified map of Chile from 40 to $51.5^{\circ} \mathrm{S}$. Names in bold and in italics represent records shown in this figure or discussed in the text, respectively.

and San Quintin glaciers during the last 125 yr (Fig. 9). Our data also allow us to add an advance of the western NPI glaciers in 1790-1830 AD.

\subsection{Climatic parameters driving Gualas glacier variability}

In order to understand the possible climatic origin of Gualas glacier fluctuations during the last $5400 \mathrm{yr}$, we compared our glacier variability record to several independent sea surface temperature (SST) and pollen (used here as a proxy for precipitation) records, located on the same (western) side of the Andes (Lumley and Switsur, 1993; Bennett et al., 2000; Lamy et al., 2002; Mohtadi et al., 2007) (Fig. 10). Unfortunately, precipitation and temperature proxy records from
Northern Chilean Patagonia are rare, and no direct air temperature record is available.

For precipitation, we used the concentration of Nothofagus dombeyi-type pollen of Laguna Stibnite (Taitao Peninsula, $46^{\circ}$ S; Lumley and Switur, 1993; Bennett et al., 2000), following the transfer function of Tonello et al. (2009), who demonstrated that Nothofagus dombeyi-type is highly positively correlated to annual precipitation. Since the Laguna Stibnite record does not cover the last millennium, we added the pollen-derived annual precipitation record of Heusser and Streeter (1980) for the last $1200 \mathrm{yr}$ (Alerce, $41^{\circ} \mathrm{S}$ ). Although other pollen records from Taitao Peninsula exist (Bennett et al., 2000), the record of Laguna Stibinite seems to be the most sensitive to climate during the Holocene. The precipitation record shows an increasing trend in annual precipitation 
starting at $4100 \mathrm{cal}$ yr BP and lasting until $800 \mathrm{cal}$ yr BP, with maximum levels between 3100 and $1900 \mathrm{cal} \mathrm{yr} \mathrm{BP} \mathrm{(Fig.} \mathrm{10).}$ This record is in agreement with the pollen record of Heusser and Streeter (1980) at $41^{\circ} \mathrm{S}$, which shows a similar decrease in precipitation between 1200 and $500 \mathrm{cal} \mathrm{yr} \mathrm{BP}$, and an increase in precipitation at 500-100 cal yr BP (Fig. 10).

Except for the Alerce record $\left(41^{\circ} \mathrm{S}\right.$, Heusser and Streeter, 1980), no Holocene air temperature record exists for the region. However, two accurate and relatively high-resolution SST records are available from sites GeoB3313-1 $\left(41^{\circ} \mathrm{S}\right.$; Lamy et al., 2002) and GeoB7186-3 (44 ${ }^{\circ}$ S; Mohtadi et al., 2007). The GeoB3313-1 record shows a gradual decrease in SST after $5500 \mathrm{cal}$ yr BP, which becomes more pronounced after 800 cal yr BP (Fig. 10). At $44^{\circ} \mathrm{S}$, core GeoB7186-3 shows a similar $1-2^{\circ} \mathrm{C}$ cooling starting at $1300 \mathrm{cal} \mathrm{yrBP}$, in agreement with the SST record of Jacaf fjord (PC33; Sepúlveda et al., 2009) and with the SST data recently obtained on cores JPC42 and MD07-3124 at 50-51 ${ }^{\circ} \mathrm{S}$ (Fig. 10; Caniupán, 2011). A synchronous cooling of the atmosphere during the Late Holocene is also described by Heusser and Streeter (1980). The high-resolution 1100-yr-long record of Neukom et al. (2010b) is in agreement with summer air temperature fluctuations of $\sim 2{ }^{\circ} \mathrm{C}$ during the last millennium.

It is evident from Fig. 10 that the main Gualas glacier advance at $\sim 4180-850$ cal yr BP is synchronous with the large increase in precipitation, as recorded in Laguna Stibnite, but that it does not correspond to any change in SST. The relatively cool SST that prevailed at the time may have promoted the advance but evidently did not trigger it. It is also remarkable that the highest reconstructed precipitation occurs between $\sim 3100$ and 1900 cal yr BP (Fig. 10), a timeinterval that corresponds to the second Neoglacial advance, which many authors consider as the most extended (e.g. Aniya, 1995; Harrison et al., 2008; Mardones et al., 2011). Similarly, the retreat of Gualas glacier at $850 \mathrm{cal} \mathrm{yr}$ BP cannot be explained by a change in SST since the data show an intensified cooling during the last millennium (Fig. 10). This retreat, however, matches the decrease in precipitation observed in the Laguna Stibnite and Alerce records (Fig. 10). Although Gualas glacier may have been a tidewater glacier, and therefore relatively insensitive to climate, during its main advance in $\sim 4180-850$ cal yr BP, its rapid retreat was very likely driven by climate, i.e. a decrease in precipitation. Finally, the secondary advances of Gualas glacier at $1750-1935 \mathrm{AD}$ could have resulted from the increase in precipitation between 1450 and $1850 \mathrm{AD}$, as demonstrated by the Alerce record. Higher winter precipitation before $\sim 1900 \mathrm{AD}$ was also described by Neukom et al. (2010a). Again, no change in SST can explain these secondary glacier advance/retreat cycles.

These results suggest that the fluctuations of Gualas glacier during the last $5400 \mathrm{yr}$ were mainly driven by changes in precipitation, supporting the observations of Warren (1993), Winchester and Harrison (1996), and Harrison and Winchester (1998), for the variations of the San Rafael,
Gualas, Reicher and San Quintin glaciers during the last century. Our record is in agreement with the interpretation of Warren and Sugden (1993) that glaciers on the western flanks of the icefields respond to changes in precipitation and are "accumulation-driven". They do not refute the hypothesis that the fluctuations of glaciers on the eastern flanks are driven by changes in temperature and hence are "ablationdriven", due to the steepness of the precipitation gradient over the NPI (Warren and Sugden, 1993). Although all Patagonian glaciers are affected by temperature changes at glacial-interglacial timescales (Hulton et al., 2002), the western NPI glaciers were most likely driven by changes in precipitation during most of the Holocene.

\section{Conclusions}

For the first time in northern Patagonia, we have reconstructed the mid- to late-Holocene evolution of an outlet glacier of the western side of the NPI using a glacio-marine record from the Chilean fjords. Our results demonstrate that the Aniya-type chronology of glacier fluctuations, which was constructed from minimal radiocarbon ages obtained on SPI moraines, is also valid for the western side of the NPI. Our results are consistent with a main advance of Gualas glacier at $4180-850$ cal yr BP, which can be subdivided into three secondary advance/retreat cycles, as well as three short-term variations between 1750 and $1935 \mathrm{AD}$. In addition, historical documents show that Gualas glacier has retreated by approximately $8.9 \mathrm{~km}$ since $1898 \mathrm{AD}$. Our results allow us to propose that the fluctuations of Gualas glacier, and most likely all western NPI glaciers, during the last $5400 \mathrm{yr}$ were mainly controlled by changes in precipitation rather than temperature. Precipitation records are however very scarce in the region and more well-calibrated precipitation records are needed to confirm this interpretation. Future precipitation records should also focus on reconstructing seasonal changes in precipitation (e.g. Neukom et al., 2010a), since glacier mass balances are mostly affected by winter precipitation, i.e. deposited as snow. Our results do not exclude the possibility that glaciers on the eastern flank of the NPI are ablation-driven, i.e. controlled by changes in temperature. Above a certain temperature threshold, temperature could play a more significant role in controlling the ablation of western NPI glaciers. Precipitation may therefore not remain the main driver of western NPI glacier fluctuations in a warmer future climate.

Acknowledgements. This research was supported by an EU FP6 Marie Curie Outgoing Fellowship to S.B. Cruise NBP0505 was funded by the US National Science Foundation, Office of Polar Programs grant number NSF/OPP 03-38137 to J. Anderson (Rice University) and J. Smith Wellner (University of Houston). The Cimar-7 Program was supported by the Chilean National Oceanographic Committee (CONA, Grant C7F 01-10 to S. Pantoja). We thank the curators of the Florida State University Antarctic Marine 
Geology Research Facility (Simon Nielsen and Lindsey Geary), for their assistance with shipping core JPC14 to WHOI. We are grateful to L. Giosan and I. Buynevich (WHOI) for providing access to the ITRAX XRF core scanner and to the Bartington magnetic susceptibility system, respectively, and to Tim Ferdelman, Andrea Schipper and Thomas Max (MPI, Bremen, Germany) for allowing us to use the UIC Coulometer. K. Bennett (Queen's University Belfast) provided the Laguna Stibnite data. We acknowledge R. Fernandez (Rice University) for stimulating discussions and for providing the bathymetric and seismic data. Two anonymous reviewers provided constructive comments on an earlier version of this paper. S.B. is currently a postdoctoral fellow of the Flemish Research Foundation (FWO, Belgium).

Edited by: T. Kiefer

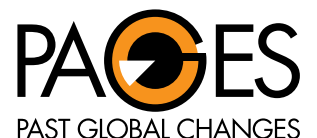

The publication of this article was sponsored by PAGES.

\section{References}

Aniya, M.: Glacier inventory for the Northern Patagonia Icefield, Chile, and variations 1944/45 to 1985/86, Arctic Alpine Res., 20, 179-87, 1988.

Aniya, M.: Glacier variation in the North Patagonian Icefield, Chile, between 1985/86 and 1990/91, Bull. Glacier Res., 10, 83-90, 1992.

Aniya, M.: Holocene glacial chronology in Patagonia: Tyndall and Upsala Glaciers, Arctic Alpine Res., 27, 311-322, 1995.

Aniya, M.: Holocene variations of Ameghino Glacier, southern Patagonia, Holocene, 6, 247-252, 1996.

Araneda, A., Torrejón, F., Aguayo, M., Torres, L., Cruces, F., Cisternas, M., and Urrutia, R.: Historical records of San Rafael Glacier advances (North Patagonian Icefield): another clue to "Little Ice Age" timing in southern Chile?, Holocene, 17, 987998, 2007.

Bennett, K. D., Haberle, S. G., and Lumley, S. H.: The Last GlacialHolocene transition in southern Chile, Science, 290, 325-328, 2000.

Bertrand, S., Hughen, K., Sepúlveda, J., and Pantoja, S.: Geochemistry of surface sediments from the fjords of Northern Chilean Patagonia $\left(44-47^{\circ} \mathrm{S}\right)$ : Spatial variability and implications for paleoclimate reconstructions, Geochim. Cosmochim. Ac., 76, 125146, 2012.

Caniupán, A. M.: Paleoenvironmental history of the Chilean fjord region and the adjacent southeast Pacific over the last $60 \mathrm{kyr} B P$ : A multiproxy analysis on high resolution sediment cores, $\mathrm{PhD}$ thesis, University of Bremen, Germany, 184 pp., 2011.

Corominas, J.: Diccionario crítico etimológico de la Lengua Castellana, IV volúmenes, Editorial Gredos, 1976.

Fenn, C. R. and Gomez, B.: Particle size analysis of the sediment suspended in a proglacial stream: Glacier de Tsijiore Nouve, Switzerland, Hydrol. Process., 3, 123-135, 1989.

Fernandez, R., Anderson, J., Bertrand, S., and Wellner, J.: The Holocene seismo-stratigraphic record of climate and environmental change from Gualas Glacier, Golfo Ele- fantes, Northern Patagonia $\left(46.5^{\circ} \mathrm{S}\right)$, Holocene, online first: doi:10.1177/0959683611425545, 2012.

Folk, R. L. and Ward, W. C.: Brazos river bar: a study in the signifiance of grain size parameters, J. Sediment. Petrol., 27, 3-26, 1957.

Glasser, N. F., Harrison, S., Winchester, V., and Aniya, M.: Late Pleistocene and Holocene paleoclimate and glacier fluctuations in Patagonia, Global Planet. Change, 43, 79-101, 2004.

Glasser, N. F., Harrison, S., Jansson, K. N., Anderson, K., and Cowley, A.: Global sea-level contribution from the Patagonian Icefields since the Little Ice Age maximum, Nat. Geosci., 4, 303307, 2011.

Haberle, S. G. and Lumley, S. H.: A postglacial eruption history of Hudson volcano, southwestern Chile, J. Volcanol. Geoth. Res., 84, 239-256, 1998.

Haritashya, U. K., Kumar, A., and Singh, P.: Particle size characteristics of suspended sediment transported in meltwater from the Gangotri Glacier, central Himalaya - An indicator of subglacial sediment evacuation, Geomorphology, 122, 140-152, 2010.

Harrison, S. and Winchester, V.: Historical fluctuations of the Gualas and Reicher glaciers, North Patagonian Icefield, Chile, Holocene, 8, 481-485, 1998.

Harrison, S., Winchester, V., and Glasser, N.: The timing and nature of recession of outlet glaciers of Hielo Patagónico Norte, Chile, from their Neoglacial IV (Little Ice Age) maximum positions, Global Planet. Change, 59, 67-78, 2007.

Harrison, S., Glasser, N. F., Haresign, E., Winchester, V., Warren, C. R., Duller, G. A. T., Ivy-Ochs, S., Jansson, K., Bailey, R., and Kubik, P.: Glaciar Leon, Chilean Patagonia: Late Holocene chronology and geomorphology, Holocene, 18, 643-652, 2008.

Heusser, C. J.: Late-Pleistocene environments of the Laguna de San Rafael area, Chile, Geogr. Rev., 50, 555-577, 1960.

Heusser, C. J. and Streeter, S. S.: A temperature and precipitation record of the past 16,000 years in southern Chile, Nature, 210, 1345-1347, 1980.

Hieke, W.: Transparent layers in seismic reflection records from the central Ionian Sea (Mediterranean)-evidence for repeated catastrophic turbidite sedimentation during the Quaternary, Sediment. Geol., 135, 89-98, 2000.

Huang, S., Sholkovitz, E., and Conte, M.: Application of hightemperature fusion for analysis of major and trace elements in marine sediment trap samples, Limnol. Oceanogr.: Methods, 5, 13-22, 2007.

Hulton, N. R. J., Purves, R. S., McCulloch, R. D., Sugden, D. E., and Bentley, M. J.: The Last Glacial maximum and deglaciation in southern South America, Quaternary Sci. Rev., 21, 233-241, 2002.

Lamy, F., Rühlemann, C., Hebbeln, D., and Wefer, G.: High- and low-latitude climate control on the position of the southern PeruChile Current during the Holocene, Paleoceanography, 17, 1028, doi:10.1029/2001PA000727, 2002.

Lemmen, D. S., Gilbert, R., Smol, J. P., and Hall, R. I.: Holocene sedimentation in glacial Taikutaaq Lake, Baffin Island, Can. J. Earth Sci., 25, 810-823, 1988.

López, P., Chevallier, P., Favier, V., Pouyaud, B., Ordenes, F., and Oerlemans, J.: A regional view of fluctuations in Glacier length in southern South America, Global Planet. Change, 71, 85-108, 2010.

Lumley, S. H. and Switsur, R.: Late Quaternary chronology of the 
Taitao Peninsula, southern Chile, J. Quaternary Sci., 8, 161-165, 1993.

Mann, D. H.: Reliability of a fjord glaciers fluctuations for paleoclimatic reconstructions, Quaternary Res., 25, 10-24, 1986.

Mardones, M., Gonzalez, L., King, R., and Campos, E.: Variaciones glaciales durante el Holoceno en Patagonia Central, Aisen, Chile: evidencias geomorfologicas, Andean Geol., 38, 371-392, 2011.

McCormac, F. G., Hogg, A. G., Blackwell, P. G., Buck, C. E., Higham, T. F. G., and Reimer, P. J.: SHCAL04 Southern Hemisphere calibration, 0-11 Cal kyr B.P, Radiocarbon, 46, 10871092, 2004.

Mercer, J. H.: Variations of some Patagonian glaciers since the lateGlacial: II, Am. J. Sci., 269, 1-25, 1970.

Mercer, J. H.: Glacial history of southernmost South America, Quaternary Res., 6, 125-166, 1976.

Mercer, J. H.: Holocene glacier variations in southern Patagonia, Striae, 18, 35-40, 1982.

Mohtadi, M., Romero, O. E., Kaiser, J., and Hebbeln, D.: Cooling of the southern high latitudes during the Medieval Period and its effect on ENSO, Quaternary Sci. Rev., 26, 1055-1066, 2007.

Murray, R., Miller, D., and Kryc, K.: Analysis of major and trace elements in rocks, sediments, and interstitial waters by inductively coupled plasma-atomic emission spectrometry (ICP-AES), ODP Technical Note, 29, 2000.

Neukom, R., Luterbacher, J., Villalba, R., Küttel, M., Frank, D., Jones, P. D., Grosjean, M., Esper, J., Lopez, L., and Wanner, H.: Multi-centennial summer and winter precipitation variability in southern South America, Geophys. Res. Lett., 37, L14708, doi:10.1029/2010GL043680, 2010a.

Neukom, R., Luterbacher, J., Villalba, R., Küttel, M., Frank, D., Jones, P. D., Grosjean, M., Wanner, H., Aravena, J. C., Black, D. E., Christie, D. A., D’Arrigo, R., Lara, A., Morales, M., Soliz-Gamboa, C., Srur, A., Urrutia, R., and von Gunten, L.: Multiproxy summer and winter surface air temperature field reconstructions for southern South America covering the past centuries. Clim. Dynam., 37, 35-51, doi:10.1007/s00382-010-07933, 2010b.

Oerlemans, J.: Extracting a climate signal from 169 glacier records, Science, 308, 675-677, 2005.

Pagés, A.: Gran diccionario de la Lengua Castellana (de autoridades) con ejemplos de buenos escritores antiguos y modernos, Imprenta de Ángel Ortega, undated (in Spanish).

Perdue, E. M. and Koprivnjak, J.-F.: Using the $\mathrm{C} / \mathrm{N}$ ratio to estimate terrigenous inputs of organic matter to aquatic environments, Estuar. Coast. Shelf S., 73, 65-72, 2007.

Pfeffer, W. T.: Tidewater glaciers move at their own pace, Nature, 426, p. 602, 2003.

Porter, S. C.: Onset of Neoglaciation in the Southern Hemisphere, J. Quaternary Sci., 15, 395-408, 2000.

Post, A., O’Neel, S., Motyka, R. J., and Streveler, G.: A complex relationship between calving glaciers and climate, EOS, 92, 305306, 2011.
Rignot, E., Rivera, A., and Casassa, G.: Contribution of the Patagonia Icefields of South America to sea level rise, Science, 302, 434-437, 2003.

Rivera, A., Benham, T., Casassa, G., Bamber, J., and Dowdeswell, J. A.: Ice elevation and areal changes of glaciers from the Northern Patagonia Icefield, Chile, Global Planet. Change, 59, 126137, 2007.

Sepúlveda, J., Pantoja, S., Hughen, K. A., Bertrand, S., Figueroa, D., León, T., Drenzek, N. J., and Lange, C.: Late Holocene sea-surface temperature and precipitation variability in northern Patagonia, Chile (Jacaf Fjord, $44^{\circ}$ S), Quaternary Res., 72, 400 409, 2009.

Simpson, E.: Esploraciones hechas por la corbeta Chacabuco al mando del capitan de fragata D. Enrique M. Simpson en los archipiélagos de Guaitecas, Chonos i Taitao, Anuario idrográfico de la Marina de Chile, 1, 3-147, 1875 (in Spanish).

Steffen, H.: Viajes de exploracion i estudio en la Patagonia occidental 1892-1902, Imprenta Cervantes, 1910 (in Spanish).

Steffen, H.: Westpatagonien. Die Patagonischen Kordilleren und Ihre Randgebiete, Berlin, 1919.

Steffen, H.: Patagonia Occidental. Las Cordilleras Patagonicas y sus regiones circundantes, Ediciones de la Universidad de Chile, 1947 (in Spanish).

Szczuciński, W., Zajączkowski, M., and Scholten, J.: Sediment accumulation rates in subpolar fjords - impact of post-Little Ice Age glaciers retreat, Billefjorden, Svalbard, Estuar. Coast. Shelf S., 85, 345-356, 2009.

Tonello, M. S., Mancini, M. V., and Seppä, H.: Quantitative reconstruction of Holocene precipitation changes in southern Patagonia, Quaternary Res., 72, 410-420, 2009.

Verardo, D., Froelich, P., and McIntyre, A.: Determination of organic carbon and nitrogen in marine sediments using the Carlo Erba NA-1500 analyzer, Deep-Sea Res., Part A, 37, 157-165, 1990.

Volland, S., Sturm, M., Lukas, S., Pino, M., and Müller, J.: Geomorphological and sedimentological evolution of a lake basin under strong volcano-tectonic influence: the seismic record of Lago Calafquén (south-central Chile), Quatern. Int., 161, 32-45, 2007.

Warren, C.: Rapid recent fluctuations of the calving San Rafael glacier, Chilean Patagonia: climatic or non-climatic?, Geogr. Ann. A, 75, 111-125, 1993.

Warren, C. and Aniya, M.: The calving glaciers of southern South America, Global Planet. Change, 22, 59-77, 1999.

Warren, C. and Sugden, D. E.: The Patagonian Icefields: a glaciological review, Arctic Alpine Res., 25, 316-331, 1993.

Winchester, V. and Harrison, S.: Recent oscillations of the San Quintin and San Rafael glaciers, Patagonian Chile, Geogr. Ann. A, 78, 35-49, 1996.

Yde, J. C. and Paasche, Ø.: Reconstructing climate changes: Not all glaciers suitable, EOS, 91, 189-190, 2010. 